\section{SIR JOHN DONNELLY ON TECHNICAL EDUCATION.}

$A \mathrm{~T}$ the first ordinary meeting of the new session of the Society of Arts, Major-General Sir John Donnelly delivered an address in which he dealt with some points in the history of the Society, and especially with those connected with the promotion of education. The following is a condensed report of his remarks bearing upon the development of technical instruction :-

In 1868, a Conference on Technical Education was held by the Society of Arts, and shortly afterwards-on March 24, I868-on the motion of Mr., now Sir B. Samuelson, Bart., the House of Commons granted a Select Committee, of which he was appointed chairman, "to inquire into the provisions for giving instruction in theoretical and applied science to the industrial classes." The first three of their conclusions were(I) That, with the view to enable the working classes to benefit by scientific instruction, it is of the utmost importance that efficient elementary instruction should be within the reach of every child ; (2) that unless regular attendance of the children for a sufficient period can be obtained, little can be done in the way of their scientific instruction; (3) that elementary instruction in drawing, in physical geography, and in the phenomena of nature should be given in elementary schools. Throughout these discussions the object-lesson afforded by the Paris Exhibition of 1867 was universally acknowledged to be the main feature of the movement.

Sir John Donnelly brought before the Society in 1872 a scheme for examinations in technology, which were to be supplementary to the examinations of the Science and Art Department. The scheme did not meet with much enthusiasm, and manufacturers set themselves against it on the grounds that trade secrets should not be the talk of the class-room. However, since then the examinations have been very largely developed by the City and Guilds of London Institute.

Owing to a set of circumstances, with which everyone is now thoroughly conversant, there was, shortly after the passing of the Technical Instruction Act, in 1889 , a great windfall for technical instruction. Under the Customs and Excise Act of I890, the residue, amounting to something over three-quarters of a million of money in England and Wales, became applic. able to technical education. It has been so applied very largely. From a recent return it appears that, of the forty-nine County Councils, excluding Wales and Monmouth, forty-one are applying the whole, and eight a part of the residue to technical education. Of the sixty-one County Boroughs, fifty-three are applying the whole, and seven a part of the residue to technical education; while in one case only (the County Borough of Preston) the residue is being applied wholly to relief of rates. Further than this, ten County Boroughs are, in addition, levying a rate under the Technical Instruction Acts.

For the year 1893-94, the forty-nine County Councils have allocated about $£ 465,000$, and the County Boroughs about $f_{16} 1,000$ from the Customs and Excise grant, besides raising over $£ 12,700$ by rates. This makes a total of almost exactly $£ 626$, o0o provided in England alone for technical instruction for the year, independent of the grants from the Science and Art Department.

It is purely at the option of local authorities whether they apply the "beer" money to technical education, or whether they use it in relief of the rates. It is very gratifying to see the extent to which they have devoted it to the former object, and it shows that the operations of the Science and Art Department, the Society of Arts, the City and Guilds of London, and other bodies which had previously been engaged in the movement, have not been unfruitful. But unquestionably a grea danger lurks around a sudden outburst of zeal of this kind. How far have the public generally been convinced of the efficacy of science and art and technical instruction, and the advantage of spending all the money on it, rather than in relief of rates? or how far have they been only momentarily carried away un. willing captives at the chariot-wheels of the enthusiasts? How soon will the pendulum of public opinion which has been so suddenly and so severely forced in one direction swing back again? Or-a still greater danger-how soon will the critic, the cynic, and the "practical" man commence their innings by asking to have the account balanced and the profit shown? There are already murmurings in the air : did not our fore fathers get on very well without technical education? or how is it that we stand-or, at least, stood-at the head of manu. facturing and commercial fame and engineering ability? At all events, if you cannot show any fruit let us have an inquiry; dig up the plant and have a look at its roots to see that we have planted the right sort.

Now what is this "technical instruction" with which the country is so much occupied at the present time? It is defined. in the Act of 1889 as instruction in the principles of science and art applicable to industries, and in the application of special branches of science and art to specific industries or employ. ments, as well as in modern languages and commerçial and agricultural subjects, but not in teaching the practice of any trade, or industry, or employment.

The Act, in fact, provides for instruction in technology and not in technics. Besides, though the definition clause is careful to indicate that the principles of science and art are to be cultivated, the title of the Act appeals to the sympathy of the great mass who always clamour for a short cut-some way for arriving at the money-making application of science and of art without that preliminary study which is so laborious and apparently unremunerative.

After dwelling upon changes of style in artistic work and design, Sir John Donnelly went on to say that every now and then we hear a great outcry against South Kensington and its "system." And if South Kensington now, why not in a few years hence the technical schools and courses of instruction which are being set up with so much care and thought in all parts of the country? This danger is already felt by many who are interested in technical instruction. The Science and Art Department could always point to the fact that, if its science teaching was wrong, it erred in good company, for the syllabuses were prepared, and the examinations were conducted by some of the most eminent men of science of the day.

But to whom can the local authorities under the Technical Instruction Act appeal ? It seemed to him that for their own satisfaction, and for the future stability of technical instruction, they will desire, instead of remaining, as it were, isolated and self-contained, to have an influential examining and inspecting board, to which they might refer, if they found it desirable, for assistance and advice. There are at present several bodies partially covering the ground - but only partially, and there is the great disadvantage of a want of unity. He threw out the suggestion that the Society of Arts, which is at present covering part of the field, should take the initiative in bringing all these bodies together, so that they may form some kind of joint board, or at least co-operate.

\section{THE BATTLE OF THE FORESTS. ${ }^{1}$}

$$
\text { I. }
$$

THE earth is a potential forest. Given time, freedom from geologic revolutions and from interference by man, the tree growth must finally dominate everywhere, with few excepted localities.

Its perennial nature and its elevation in height above all other forms of vegetation, together with its remarkable recuperative powers, assure to the arborescent flora this final victory over its competitors.

So impressed was Dr. Asa Gray with the persistence of individual tree life that he questioned whether a tree need ever die : "For the tree (unlike the animal) is gradually developed by the successive addition of new parts. It annually renews not only its buds and leaves, but its wood and its roots; everything, indeed, that is concerned in its life and growth. Thus, like the fabled Æsson, being restored from the decrepitude of age to the bloom of early youth, the most recent branchlets being placed by means of the latest layer of wood in favourable communication with the newly-formed roots, and these extending at a corresponding rate into fresh soil, why has not the tree all the conditions of existence in the thousandth that is possessed of in the hundredth or the tenth year of its age?

"The old and central part of the trunk may, indeed, decay, but this is of little moment, so long as new layers are regularly formed at the circumference. The tree survives, and it is difficult to show that it is liable to death from old age in any proper sense of the term."

I A lecture delivered by Prof. B. E. Fernow, Chief of the Forestry Department of Agriculture, U.S.A., during the Brooklyn meeting of the American Associalion for the Advancement of Science.

$$
\text { No. } 1 \text { jC9, VOI. } 5 \text { I] }
$$


However this may be, we know trees succumb to external causes. Nevertheless, they are perennial enough to outlive aught else, "to be the oldest inhabitants of the globe, to be more ancient than any human monument, and exhibit in some of the survivors a living antiquity compared with which the mouldering relics of the earliest Egyptian civilisation, the pyramids themselves, are but structures of yesterday." The dragon trees, so called, found on the island of Teneriffe, off the African coast, are believed to be many thousand years old. The largest is only 15 feet in diameter and 75 feet high. Our sequoias are more rapid growers, and attain in 3000 to 4000 years, which may be the highest age of living ones, more than double these dimensions.

While this persistence of life is one of the attributes which in the battle for life must count of immeasurable advantage, the other characteristic of arboreal development, its elevation in height above everything living, is no less an advantage over all competitors for light, the source of all life. Can there be any doubt that in this competition size must ultimately triumph, and the undersized go to the wall?

Endowed with these weapons of defensive and offensive warfare, forest growth, through all geologic ages during which the earth supported life, has endeavoured, and no doubt to a degree succeeded, in gaining possession of the earth's surface.

As terra firma increased emerging in islands above the ocean, so increased the area of forest, changing in composition to correspond with the change of physical and climatic conditions.

As early as the Devonian age, when but a small part of our continent was formed, the mud flats and sand reefs, ever increasing by new accumulations under the action of the waves and currents of the ocean, were changed from a bare and lifeless world above tide level to one of forest-clad hills and dales.

Not only were such quaint forms as the tree rushes Calamites, Lepidodendron and Sigillaria present, but the prototype of our pine, the Dadoxylon, had made its appearance.

The same class of flowerless plants known as vascular cryptogams, with the colossal tree ferns added, became more numerous and luxuriant in the Carboniferous age, as well as the flowering Sigillaria and coniferous. Dadoxylon. This vegetation probably spread over all the dry land, but the thick deposits of vegetable remains accumulating in the marshy places under dense jungle growth and in shallow lakes with floating islands, were finally, in the course of geologic revolutions, turned into the great coal fields.

In those and subsequent geologic times some of the floral types vanished altogether and new ones originated, so that at the end of Mesozoic times a considerable change in the land. scape had taken place.

In addition to coniferous trees, the palms appeared, and also the first of angiosperms, such as the oak, dogwood, beech, poplar, willow, sassafras, and tulip tree. Species increased in numbers, adapted to all sorts of conditions ; the forest in a most varied and luxuriant form climbed the mountain-sides to the very crests, and covered the land to the very poles with a flora of tropical and semi-tropical species.

Then came the levelling process and other changes of postTertiary or Quaternary times; the glaciation of lands in northern latitudes, with the consequent changes of climate, which brought about corresponding changes in the ranks of the forest, killing out many of the species around the north pole. Only the hardier races survived, and these were driven south ward in a veritable rout.

When these boreal times subsided in a degree, the advance of the forest was as sure as before, but the battle order was somewhat changed to suit the new conditions of soil and climate. Only the hardiest tribes could regain the northernmost posts, and these found their former places of occupancy changed by fluvial and lacustrine formations and the drifts borne and deposited by the ice-sheets, while some by their constitution were entirely unfitted from engaging in a northern campaign, or found insurmountable barriers in the refrigerated east-west elevations of Europe and Western Asia.

In addition, there had come new troubles from volcanic eruptions, which continually wrested the reconquered ground from the persistent advance guards of the arboreal army, annihilating them again and again.

Finally, when the more settled geologic and climatic conditions of the present era arrived, and the sun rose over a world ready for human habitation, man found what we are pleased to call the virgin forest-a product of long-continued evolutionary changes-occupying most, if not all the clry land, and ever intent upon extending its realm.

This prehistoric view of the battle of the forest cannot be left without giving some historic evidences of its truth.

Not only have palæobotanists unearthed the remnants of the circumpolar flora, which give evidence that it resenbled that of present tropic and semi-tropic composition, but they have also shown that sequoias, magnolias, liquidambars and hickories existed in Europe and on our own continent in regions where they are now extinct. We have also evidences of the repeated successes and reverses of the forest in its attempts to establish itself through long geologic transformations.

One of the most interesting evidences of these vicissitudes in the battle of the forest is represented in a section of Amethyst Mountain in Yellowstone National Park, exhibiting the remains of fifteen forest growths, one above the other, buried in the lava. Again and again the forest subdued the inhospitable excoriations; again and again it had to yield to superior force.

Among these petrified witnesses of former forest glory, magnolia, oak, tulip tree, sassasfras, linden and ash have been identified, accompanying the sequoia in regions where now only the hardiest conifer growths of pines and spruces find a congenial climate.

As the forest formed and spread thus during the course of ages, so does it form and spread to-day, unless man, driven by the increasing needs of existence, checks its progress and reduces its area by the cultivation of the soil. This natural extension of the forest cover or afforestation takes place readily whenever soil and climate is favourable, but it is accomplished just as surely, though infinitely slower, in unfavourable situations. On the naked rock, the coarse detritus and gravel beds, on the purely siliceous sand deposits of river and ocean, or in the hot dry plains, the preliminary pioneer work of the lower vegetation is required. Algæ, lichens, mosses, grasses, herbs, and shrubs must precede to cultivate the naked rock, to mellow the rough moisture by shading the ground, and gradually render it fit for the abode of the forest monarch. The army of soilmakers and soil-breakers, the pioneers, as it were, of the forest, are a hardy race, making less demands for their support than those that follow. They come from different tribes, according to the soil conditions in which they have to battle.

The aspen (Populus tremuloides) is one of these forerunners, which is readily wafted by the winds over hundreds of miles, readily germinates and rapidly grows under exposure to full sunlight, and even now in the Rocky Mountains and elsewhere quickly takes possession of the areas which man has ruthlessly destroyed by fire. This humble and ubiquitous, but otherwise almost useless, tree is nature's restorative, covering the sores and scalds of the burnt mountain side, the balm poured upon grievous wounds. Though short-lived, with its light summer foliage turning into brilliant golden autumn hues, it gives grateful shade and preserves from the thirsty sun and wind some moisture, so that the better kinds may thrive and take its place when it has fulfilled its mission.

One of the shrubs or half-trees which first take possession of the soil in the western mountain country is the so-called mountain mahogany (Cercocarpus ledifolius), covering the bared slopes after the fire has killed the old timber.

In other regions, as on the prairies of Iowa and Illinois, hazel bushes, or in the mountains of Pennsylvania and the Alleghanies in general, ericaceous shrubs like the laurel and rhododendrons or hawthorn, viburnum and wild cherry are the first comers, while along water-courses alders and willows crowd even the water into narrower channels, catching the soil which is washed from the hill-sides and increasing the land area.

One of the most interesting soil-makers, wresting new territory from the ocean itself, is the mangrove along the coast of Florida. Not only does it reach out with its aerial roots, entangling in their meshes whatever litter may float about, and thus gradually building up the shore, but it pitches even its young brood into the advance of the battle, to wrestle with the waves, and gain a foothold as best it may.

Not less interesting in this respect is that denizen of the southern swamp, the bald cypress, with its curious root excres. cences known as cypress knees, which, whatever their physiologic significance, are most helpful in expediting changes of water into land sufficiently dry to be capable of supporting the more fastidious species in regard to moisture and conditions.

On the dry hot mesas, and in the arroyos of the south-western 
tier of our States and Territories, we meet a different set of skirmishers following up the huge cacti and agaves, which together with the tree yuccas, penetrate into the very desert. In these regions the mesquite or algaroba and others of the acacia tribe form the second phalanx, as it were, gradually advancing their lines in spite of adverse conditions. In other regions the pine, satisfied with but scanty favour of soil moisture, and the spruce, able to sustain life in shallow soil, and the fir, in the higher, colder, and wetter elevations, sometimes much stunted, form the skirmish line. These improve the soil in its moisture conditions by their shade, and by the foliage and litter falling and decaying they deepen the soil, forming a humus cover. The duff that is found covering the rocky subsoil of the Adirondacks is formed in this way at the rate of about one foot in 500 years. They are soon followed by the birch, maple, elm, and ash, and in moister situations by the oak-first, that hardy pioneer, the black oak tribe, and then the more fastidious white oak, with whom the slower but persistent hickories, beeches, and other shade-enduring species begin to quarrel for the right of occupancy of the ground, until the battle is no longer that of the forest against the elements and lower vegetation, but between the mighty conquerors themselves. This struggle we can see going on in our primeval forests, wind, storms, and decay acting as allies now to one, now to the other side, and thus changing the balance of power again and again.

In this struggle for supremacy between the different arborescent species the competition is less for the soil than for the light, especially for tree growth. It is under the influence of light that foliage develops, and that leaves exercise their functions and feed the tree by assimilating the carbon of the air and transpiring the water from the soil. The more foliage and the more light a tree has at its disposal, the more vigorously it will grow and spread itself.

Now the spreading oak or beech of the open field finds close neighbours in the forest, and is narrowed in from all sides and forced to lengthen its shaft, to elevate its crown, to reach up for light, if it would escape being overshadowed, repressed, and perhaps finally killed by more powerful densely-foliaged competitors.

The various species are differently endowed as regards the amount of light which they need for their existence. Go into the dense forest and see what kinds of trees are vegetating in the dense shade of the older trees, and then go into the opening recently made, an abandoned field or other place, where the full benefit of light is to be had by all alike, and one will find a different set altogether occupying the ground and dominating. In the first case there may be found, perhaps, beech and suga maple or fir and spruce; in the second case aspen, poplar, willow, soft maple, oak or pine, tamarack, \&c.

All trees thrive ultimately best in full enjoyment of light. But some, like those first mentioned, can at least subsist and their foliage functionate with a small amount - they are shadeenduring kinds, usually having a dense foliage, many leaves, and each one needs to do but little work - and exert consider able shade when fully developed. Those last named, however, are light-needing kinds, and having less foliage, cannot exist long without a considerable amount of light.

To offset this drawback in the constitution of these latter, nature has endowed them as a rule with the capacity of rapid height growth, to escape their would-be suppressors ; but again, what they have gained in the rapidity of development they lose in the length of life. They are mostly short-lived species, while the shade-enduring are generally slower growers, bu persistent and long-lived. Some kinds, like most of the oaks, stand between the two ; while exhibiting a remarkable capacity of vegetation in the shade, they are really light-needing species, but comparatively slow-growers and long-lived. One of the same species behaves also somewhat differently under different soil and climatic conditions; for instance, as a rule, the lightneeding species can endure more shade on moist soils, and the shade-enduring require more light on drier soils.

In the earliest stages of life the little seedlings of most trees require partial shade, and are quite sensitive in regard to light and conditions. Some have such a small range of light and shade endurance that, while there may be millions of little seedlings sprouted, they will all perish if some of the mother trees are not removed and more light given; and they will perish equally if the old growth is removed too suddenly, and the delicate leaf structure, under the influence of direct sunlight, is made to exercise its functions beyond its capacity.
Left to itself the forest grows up, and as the individual trees develop, each trying to hold its ground and struggling for light, a natural thinning takes place, some trees lagging behind in growth and being shaded out, until in old age only as many trees remain as can occupy the ground without incommoding each other.

This struggle among the individuals goes on during their entire life. Some few shoot ahead, perhaps, because of a stronger constitution or some tavourable external cause, and over-tower their neighbours. These, lagging behind, fall more and more under the shading influence of their stronger neigh bours until entirely suppressed, when they only vegetate until they die. The struggle continues, however, among the dominant class, and it never ends.

Thus the alterations of forest growth take place, oak following pine, or pine following oak ; the poplar, birch and cherry appearing on the sunny burns, or the hickory, beech, and maple creeping into the shadier pine growths. While in the eastern forests under natural conditions the rotation of power is accomplished in at least from 300 to 500 years, the old monarchs of the Pacific, towering above all competitors, have held sway 2000 or more years. In this warfare, with changes in climatic and soil conditions going on at the same time, it may well occur that a whole race may even be exterminated.

The study of the formative period of the forest is necessary in order to show clearly that the virgin forest is a product of long struggles, extending over centuries, nay, thousands of years. Some of the mightiest representatives of the old families, which at one time of prehistoric date were powerful, still survive, but are gradually succumbing to their fate in our era.

The largest of our eastern forest trees, reaching a height of I 40 feet and diameters up to twelve feet, the most beautiful and one of the most useful, the tulip tree (Liriodendron tulipifera), is a survivor of an early era, once widely distributed, but now confined to eastern North America, and doomed to vanish soon from our woods through man's improper partisanship.

Others, like the Torreya and Cupressus, seem to have succumbed to a natural decadence, if we may judge from their confined limits of distribution. So, too, the colossal sequoias, remnants of an age when things generally were of larger size than now, appear to be near the end of their reign, while the mighty taxodium or bald cypress, the big tree of the East, still seems vigorous and prcsperous, being able to live with wet feet without harm to its constitution, weird with the grey tillandsia or Spanish moss.

Having thus scanned through the traditions of unwritten history of the battle of the forest, having seen some of the combatants in the struggle, and learned something of their methods of conquering the earth and each other, we may take a look at the condition of things on the North American continent as it presumably was in the beginning of historic times or within our century.

As far as occupancy of the soil by the forest is concerned, we find that the struggle had not yet been determined in its favour everywhere. While a vast territory on the Atlantic side and a narrower belt on the Pacific Coast, connected by a broad belt through the northern latitudes, was almost entirely under its undisputed sway, and while the backbone of the continent, the crest and slopes of the Rocky Mountains, was more or less in its possession, there still remained a vast empire in the interior unconquered.

Of parts of this territory we feel reasonably certain from strong evidences that the forest once occupied them, but has been driven off by aboriginal man, the firebrand taking sides with the grasses, and the buffalo probably being a potent element in preventing re-establishment. In other parts it is questionable whether the lines along the river-courses, the straggling trees on the plateaus and slopes, are remnants of a vanquished army or outposts of an advancing one. In some parts, like the dry mesas, plateaus and arroyos of the interior basin and the desert-like valleys toward the southern frontiers, it may reasonably be doubted whether arborescent flora has more than begun its slow advance from the outskirts of the established territory.

Certain it is that climatic conditions in these forestless regions are most unfavourable to tree growth, and it may well be questioned whather in some parts the odds are not entirely against the progress of the forest.

Temperature and moisture conditions of air and soil determine ultimately the character of vegetation, and these are

No. I 309, voL. 5I] 
dependent not only on latitude, but largely on configuration of the land, and especially on the direction of moisture-bearing winds with reference to the trend of mountains.

The winds from the Pacific Ocean striking against the coast range are forced by the expansion and consequent cooling to give up much of their moisture on the windward side; a second impact and further condensation of the moisture takes place on the Cascade range and Sierra Nevada. On descending, with consequent compression, the wind becomes warmer and drier, so that the interior basin, without additional sources of moisture and no additional cause for condensation, is left without much rainfall and with a very low relative humidity, namely, below 50 per cent. The Rocky Mountains finally squeeze out whatever moisture remains in the air currents, which arrive proportionally drier on the eastern slope. This dry condition extends over the plains until the moist currents from the Gulf of Mexico modify it. Somewhat corresponding, yet not quite, to this distribution of moisture, the western slopes are found to be better wooded than the eastern, and the greater difficulty of establishing a forest cover here must be admitted ; yet since the forest has the capacity of creating its own conditions of existence by increasing the most important factor of its life, the relative humidity, the extension of the same may only be a question of time.

Temperature extremes, to be sure, also set a limit to tree growth, and hence $t$ e so-called timber line of high mountains, which changes in altitude according to the latitude.

If now we turn our attention from the phyto-topographic consideration of the forest cover to the phyto-geographic and botanical features, we may claim that the North American forest, with 425 or more arborescent species, belonging to 158 genera, many of which are truly endemic, surpasses in variety of useful species and magnificent development any other forest of the temperature zone, Japan hardly excepted. In addition there are probably nowhere to be seen such extensive fields of distribution of single species.

These two facts are probably explained by the north-andsouth direction of the mountain ranges, which permitted a reestablishment after the Ice Age of many species farther northward, while in Europe and the main part of Asia the east-west direction of the mountains offered an effectual barrier to such re-establishment, and reduced the number of species and their field of distribution; nor are the climatic differences of differen latitudes in North America as great as in Europe, which again predicates greater extents in the fields of distribution north and south. On the other hand, the differences east and west in floral composition of the American forest are greater than if an ocean had separated the two parts instead of the prairie and plains. This fact would militate against our theory that the intermediate forestless region was or would be eventually forested with species from both the established forest regions, if we did not find some species represented in both regions and a junction of the two floras in the very region of the forestless areas.

( $T o$ be continued.)

\section{SOCIETIES AND ACADEMIES.}

\section{LONDON.}

Zoological Society, November 20.-Sir W. H. Flower, K.C.B., F.R.S., President, in the chair.-Mr. F. G. Parsons read a paper on the anatomy of Atherura africana, compared with that of other porcupines. In addition to the points mentioned by Drs. Gray and Günther, as differences between the skulls of $A$. africana and $A$. macrura, the arrangement of the fronto-nasal suture, the position of the maxillo-malar suture, and the frequent presence of an "os anti-epilepticum" were noticed.-A communication from Mr. J. T. Cunningham treated of the significance of diagnostic characters in the Pleuronectidæ. - Mr. A. Smith Woodward read a description of the so-called Salmonoid fishes of the Erglish Chalk, dealing with the osteology of Osmeroides lewesiensis, Elopopsis crassus, and Aulolepis typus. - Mr. W. Garstang read a paper on the Gastropod Colpodaspis pusilla of Michael Sars. He described a specimen of this rare mollusk found by him at Plymouth in the early part of the year. - A communication from $\mathrm{Mr}$. A. D. Bartlett gave an account of the recent occurrence in the Society's menagerie of a case of one boa swallowing another of nearly equal size. $-A$ communication from Prof. $R$. Collett contained a description of a new Agonoid fish from Kamtschatka, proposed to be called Agonus gilberti.

Royal Meteorological Society, November 2I.-Mr. R. Inwards, President, in the chair.-Dr. H. B. Guppy read a paper on suggestions as to the methods of determining the influence of springs on the temperature of a river as illustrated by the Thames and its tributaries. The methods suggested were $(I)$ comparison of the curves of the monthly means of the temperatures of the air and of the water for the river under observation with those of a river beyond the controlling influence of springs; (2) comparison of the monthly means of the temperature of the river under investigation with that of a river beyond the control of the springs ; (3) comparison of the range of the monthly means of the river temperature with that of the air in the shade ; (4) comparison of the daily range of water temperature at different stations along a river's course ; (5) comparison of sunrise observations made at different stations along a river's course; (6) comparison of observations made at different stations along a river's course at the hour of maximum temperature; $(7)$ comparison of the results obtained from a single series of observations made in one day along the whole course of a small tributary like the Wandle, or along the upper course of a larger tributary as the Kennet; and (8) determination of the distance from its sources at which the river begins to freeze.-Mr. Eric S. Bruce exhibited and described some lantern slides showing the disastrous effects of the great gale of November 17 and I8, I 893 , upon trees in Perthshire, Scotland. Mr. Alfred B. Wollaston gave an account of the formation of some water-spouts which he had observed in the Bay of Bengal.

\section{CAMBRIDGE.}

Philosophical Society, November I2.-Prof. J. J. Thomson, President, in the chair.-On the inadequacy of the cell theory and on the development of nerves, by Mr. A. Sedgwick. The author pointed out that the cell-theory, in so far as it implied that the organism was composed of cell-units derived by division from a single primitive cell-unit, the ovicell, would not bear the scrutiny of modern embryology, and that in fixing men's attention too much upon the cell as a unit of structure, it had had a retarding infuence on the progress of the knowledge of structure. He illustrated this latter point by reference to the current ideas on two important subjects : the structure of the embryonic tissue called mesenchyme, and the development of nerves. The mesenchyme is not composed of separate branched cells, but has rather a spongy or reticulate structure, and is continuous both with ectoderm and endoderm. Nerves do not develop as outgrowths of the central organ, but arise in situ from the mesenchyme. - Note on the evolution of gas by water-plants, by Mr. F. Darwin.

\section{PARIS.}

Academy of Sciences, November I9.-M. Lœwy in the chair.-After the reading of the procès verbal, the meeting was adjourned as a mark of respect to the late Czar of Russia.

\section{AMSTERdam.}

Royai Academy of Sciences, October 27.-Prof. Van de Sande Bakhuyzen in the chair.-Mr. Franchimont, in presenting Mr. H. van Erp's thesis for the Doctorate in Chemistry at the University of Leyden, entitled "Studie ober aliphatische nitraminen," described it as a summary of all the known acid and neutral nitramines and nitramides, and also of their modes of formation. In dealing with the action of water, acids and alkalies on these bodies, Mr. van Erp considers them as derived from the amide of nitric acid, and compares them to the analogous derivatives of nitrous acid, hypochlorous acid, \&c. For experimental purposes he made the unknown butyl- and hexylderivatives: nine urethanes, seven nitro-urethanes, four acid nitramines with several salts, two mixed neutral nitramines. $\mathrm{He}$ failed, however, to obtain nitro-compounds of the tertiary butyl amidoformates. He has observed that while the potassium salts of the acid nitramines yield the neutral methyl-derivatives by the action of methyliodide, the silver salts produce an isomeric methylated nitramine, or a mixture of the two. Similar observations in the case of the salts of phenylnitramine were made later by Bamberger. The behaviour of acid nitramines towards dilute sulphuric acid was studied on hexylnitramine, the result being $\mathrm{N}_{2} \mathrm{O}$, two hexanoles, a primary and a secondary 